\title{
Why continence matters: A social work perspective
}

\section{Doug Matthews}

Doug Matthews MSW (App) MANZASW is a social worker at The Princess Margaret Hospital with the Older Persons Health Specialist Service of Canterbury District Health Board and a Kiwi by choice. He has U.S. qualifications in political economy and law and New Zealand qualifications in social work and theology. He is currently undertaking postgraduate study in social gerontology at the Christchurch School of Medicine.

\section{Introduction}

The International Continence Association defines urinary incontinence (UI) as the involuntary leakage of urine (Abrams, et al., 2003; Getliffe \& Thomas, 2007). UI is a symptom or a collection of symptoms, not a disease (Hope, 2007; Perry, 2008). UI is widely underreported and undertreated (Fonda \& Newman, 2006; Getliffe \& Thomas, 2007; Lara \& Nancy, 1994). These circumstances reflect (at least in part) reluctance among many health care workers to face UI squarely (Hope, 2007; Locher, Burgio, Goode, Roth \& Rodriguez, 2002). Part of this reluctance may be attributable to lack of skills and knowledge (Getliffe \& Thomas, 2007; Hope, 2007; Locher et al, 2002). Reflective practitioners must also recognise, and guard against, being influenced by their own life experiences and beliefs (Phillips, Ray \& Marshall, 2006) and by erroneous and unhelpful beliefs in the society at large (Brashler, 2006; Getliffe \& Thomas, 2007; Hope 2007). Moreover, the failure of persons suffering chronic conditions to be 'cured' can elicit negative reactions from health workers (Brashler, 2006).

Ageism, defined as 'a set of beliefs, attitudes, social institutions, and acts that denigrate individuals or groups based on their chronological age' negatively impacts on older persons' health and well-being (Whitbourne, 2005, p. 51; see also Butler, 1975; Myers \& Schwiebert, 1996; Wilson, Ruch, Lymbery, \& Cooper, 2008). The beliefs of individuals, families and groups too often do not reflect the reality that most persons with UI can be helped (Fonda, 2006: Getliffe \& Thomas, 2007; Naughtin \& Schofield, 2009; Locher, et al., 2002). This article addresses how health care social workers can contribute to delivering this central message to clients, whanau and other caregivers.

\section{Why continence matters}

Incontinence is soul shattering. It can completely ruin the lives of those of us who are affected by it.

I've not gone out for years for fear of wetting someone's chair or car seat (Unattributed anecdote appearing in Getliffe \& Thomas, 2007, p. 6).

Some older persons find they can manage UI as a practical matter and do not seek support (Perry, 2008). Social workers with good engagement skills, however, can provide hope for 
the large number of older persons who are not managing well and / or who are unaware that there are good medical and allied health treatments available. They can also support those experiencing psychosocial distress but who have been unable or unwilling to articulate it. Examples of distress include stigma, depression, social isolation and carer stress.

\section{Stigma}

Stigma is based on social and cultural beliefs that impact not just the older person, but also family members and others close to her, often leading to 'disability by association' (Burke \& Parker, 2007, p. 7). Stigmatised conditions 'tend to take a much longer time to be declared to the doctor and even longer to family, friends and others' (Fonda \& Newman, 2006, p. 76). Many families require support to break through the 'blame, shame and guilt' that result (Rolland \& Werner-Lin, 2006).The social and cultural stigma associated with UI accounts for much of the underreporting and under-treating of the condition (Cooper, 1997) and is long-standing (Fonda \& Newman, 2006). This is not unlike the stigma that formerly attached to cancer, infertility and mental illness (Fonda \& Newman, 2006). In our youth-obsessed culture, UI has become a 'cultural symbol for the increasing dependencies of old age' (Mitteness \& Barker, 1995).

\section{Depression}

Depression in older people is often linked to physical illness; prevention or treatment of the illness is therefore a protective factor for preventing depression (Hughes, 1997; Kairuz, Zolezzi, \& Fernando, 2005). There is a relationship between stigma and depression (Fonda \& Newman, 2006). 'People with incontinence have been found to be more depressed, have higher levels of anxiety, feel more stigmatized and have poorer life satisfaction compared to people who are continent' (Getliffe \& Thomas, 2007, p. 9).

When connected with illness and disability, the effects of depression (such as depressed affect, decreased interest and pleasure in life's activities, and disruptions in appetite and sleep) are especially pernicious (Kairuz et al., 2005). The physical and economic demands on caregivers increase as sufferers lose interest in caring for themselves and, as their physical and psychological health deteriorates, simultaneously require more health-related care and expenditures (Browne, 2006). In the context of UI, deterioration in mood may also result in an increased propensity for falls, urinary tract infections, delirium, institutionalisation or even death.

\section{Social isolation}

The distress frequently associated with UI can lead to withdrawal from social interactions (Burke \& Parker, 2007; Fonda \& Newman, 2006; Shield \& Aronson, 2003; Wells \& Wells, 1997).

People avoid making social contacts and lose their confidence in personal relationships. Disgust or fear of wetting or soiling partners can cause frigidity and impotence, and catheters and appliances can have a devastating effect on body image (Getliffe \& Thomas, 2007, p. 8).

Practical obstacles abound. Persons suffering from UI often avoid public transport, with negative impacts on opportunities for work, entertainment or socialising. Stigma plays a role in social isolation, too, as older people withdraw in the face of 'ignorance and lack of tolerance' by others (Fonda \& Newman, 2006, p. 76). 


\section{Carer stress}

UI can negatively impact on the quality of life of family carers (Wagg, et al., 2008). 'Unpaid carers are an essential part of our health and social care systems, not only providing physical and emotional support, but also saving the government large amounts of money' (Jorgensen, Parsons \& Jacobs, 2009, p. 2). They are entitled to support. In its absence, UI can be the determining factor in the family's decision for residential care (Getliffe \& Thomas, 2007; Greene, 2000; Landi et al., 2003; Stewart, 2006; Taylor \& Donnelly, 2006; Wagg et al., 2008).

It is as though families can take only so much evidence of dependency. A nursing home resident I once interviewed put it like this: 'Pop smells, so into the nursing home he goes' (Shield \& Aronson, 2003, p. 152).

This attitude and others like it locate the problem in the older person, failing to take into account the systemic and multifactorial causes of chronic UI (Brashler, 2006). Accordingly, carer stress may erupt into various forms of abuse (Hope, 2007; Tomita, 2006) or, at the very least, profound feelings of anger, ambivalence or guilt (Brandon \& Jack, 1997). This often results in two clients in place of one, with the caregiver also becoming a focus of the health and social welfare system.

\section{Promoting bladder health: A biopsychosocial approach}

[F]unctional ability can be conceptualized as the dynamic interaction of an older adult's physiological status, the emotional or psychological environment, and the external or physical and social environment (Pearson, 2000, p. 19, quoted in Browne, 2006).

\section{Social work theory}

Most social workers are systems thinkers (Andreae, 1996). We have a dual mission - to promote individual and social change (Browne, 2006; Greene, 2000). Most take an ecological (person-in-environment) approach (Greene, 1999), emphasising strengths-based practices (Saleebey, 2005) that promote both self-efficacy and social transformation. From the ecological view adaptation - the integration of the person and the environment - leads to 'goodness of fit' (Compton, Gallaway, \& Cournoyer, 2005; Greene, 1999). All actors in a system have strengths. Social workers get alongside individuals, organisations and communities as they recognise and harness them.

As practitioners we must avoid an excessive focus on the person in person-in-environment, which too often 'individualis[es] social ills' (Domenelli, 2002, p. 72). This is the indictment that commentators frequently aim at a 'medical model of health care that focuses primarily on the biological causes of disease' (Browne, 2006, p. 23; Fonda \& Newman, 2006). Consider the unsupported family caregiver who abuses an untreated older relative. Where is the problem? With the carer, the older person, the culture or the health and social welfare care system?

\section{Continence promotion policy}

Unlike the United Kingdom (Wagg, et al., 2007) and Australia (Fonda \& Newman, 2006), New Zealand does not have a national continence promotion strategy. The Ministries of Health and of Social Development, in partnership with Carers NZ, the Carers Alliance and the New Zealand Continence Association, are currently working to advance New Zealand policy in the area (Carers NZ, 2009). As in the international setting (Getliffe \& Thomas, 2007), 
within New Zealand continence services are evolving at different rates, using different or no discernable models, and providing inconsistent and intermittent care.

Mapping available local services is a prerequisite to effectively utilising and improving them (Getliffe \& Thomas, 2007). Social work practitioners should check with local medical and allied health practitioners or with their local district health board to learn about continence promotion programmes and policies available to their clients. In some cases, social workers will find that there is a local or regional continence service or committee that can provide them with information about services. Needs assessment and service coordination centres of local DHBs are also good places to start. General continence questions can be fielded by the New Zealand Continence Association, which also provides a free Bladder Helpline (0800 650 659).

\section{Interdisciplinary and culturally-informed practice}

A biopsychosocial model requires the perspectives of a number of professionals to effectively deliver health services (Browne, 2006, p. 37). Specialist physiotherapists and nurse practitioners have been the major players in continence service delivery (Getliffe \& Thomas, 2007, Stewart, 2006), but the workforce is small in number relative to need. Typically, these specialists provide 'assessment, diagnosis, treatment, and management options' for the older person experiencing UI (Stewart, 2006, p. 89). They prioritise the 'bio' in biopsychosocial.

Space limitations prevent a discussion of the multifactorial causes for bladder weakness, but UI frequently manifests in one or a combination of four types: urge, stress, overflow and / or functional. Urge incontinence, sometimes called overactive bladder, is a form of involuntary voiding providing virtually no warning. Stress incontinence is the most common form of UI, and is present where there is leakage of small amounts of urine upon exertion or other stress on the pelvic floor muscles (such as laughter, sneezing or exercise). Overflow incontinence (or urinary retention) is present when the 'fullness' feeling is virtually absent and the bladder becomes so full that urine leakage results. Functional incontinence is not related to genitourinary malfunction, but is often attributable to physical disability, environmental obstacles or medications, as well as to psychological or behavioural causes. Some older people experience a combination of the above forms of UI.

All members of the older persons interdisciplinary health care team - consultants and other physicians, hospital and community nurses, physiotherapists, speech and language therapists, pharmacists, occupational therapists, needs assessors, chaplains, Maori health workers, dieticians, social workers and the like - 'are increasingly being encouraged to develop their skills in continence assessment and management' (Getliffe \& Thomas, 2007, p. 15). A good start can be made simply by routinely asking patients and older persons whether they experience urinary leakage (Hope, 2007; Horrocks, Somerset, Stoddart, \& Peters, 2004). If the health care social worker has also mapped out the specialist continence services in his or her area, as suggested above, he or she will be the right person in the right place at the right time to direct the consumer to the right service.

'Promoting health care in a multicultural society is challenging on a number of accounts, particularly around cultural issues and language barriers' (Getliffe \& Thomas, 2007, p. 17). The New Zealand Continence Association has some consumer information in Maori (0800 650 659). The Bladder \& Bowel website of Australia's Department of Health and Ageing 
has information in more than 15 languages (http:/ / www.bladderbowel.gov.au/publications / english.htm).

\section{Engagement, assessment, intervention and evaluation in promoting bladder health}

\section{Engagement}

UI is stigmatised and many - layperson and clinician alike - find it difficult to talk about (Getliffe \& Thomas, 2007). Sometimes the issue of UI will either be self-evident or the social worker will have learned about it prior to engaging with the older person (often this fact is noted in the referral). Whether known in advance or not, social workers who want to improve outcomes for older people will need to have excellent interpersonal skills .

\section{Assessment}

Bladder function ought to form a part of every routine assessment of older people (Diwan \& Balaswamy, 2006). A social worker in frequent contact with older people may choose to use standardised, validated and reliable screening and assessment tools to promote treatment and research (Berkman et al, 1999; Davey, 2002; Diwan \& Balaswamy, 2006; Kane, 2006). Some forms of the InterRAI, a comprehensive set of older persons assessment tools widely in use in New Zealand and throughout the world (Weidenbohm, et al., n.d.), includes questions about incontinence.

The International Consultation on Incontinence Modular Questionnaire - Urinary Incontinence Short Form (ICIQ-UI Short Form) is a simple, valid, reliable and responsive tool that 'allows assessment of the prevalence, frequency and perceived cause of urinary incontinence, and its impact on everyday life' (Avery, et al., 2004, p. 322). It is available in over 29 languages, including New Zealand English. Taking only minutes to complete, the ICIQ-UI Short Form contains four items that provide information on the types and impacts (including the quality of life impact) of UI.

The ICIQ-UI Short Form presents an opening for older person/ worker discussion around the topic. The results can be used to support a referral for continence services. This same tool can be administered periodically after treatment or other interventions have been commenced to measure their efficacy and duration. Licences are free to not-for-profit clinicians subject to some conditions (http: / / www.iciq.net/ ICIQ-UIshortform.html).

What are some of the possible social work interventions promoting continence for older persons currently living with UI?

\section{Providing information}

When addressing the issue of UI, begin with this simple but hopeful message: UI is not 'normal' for older people and UI is not caused by 'old age' (McInnis-Dittrich, 2005; see also Naughtin \& Schofield, 2009; Locher et al, 2002). Treatment and/or containment measures can substantially control UI in many cases, and improve a client's quality of life in many others (Getliffe \& Thomas, 2007; McInnis-Dittrich, 2005).

Treatment strategies frequently include some combination of: 
i) conservative measures, such as pelvic floor exercises, bladder control and training strategies, adjustments to diet (Locher et al, 2002) and attention to relational and environmental constraints (Wells \& Wells, 1997);

ii) medications, chiefly those which operate to increase sphincter resistance and bladder capacity (Wells \& Wells, 1997); and,

iii) surgery. Surgery is a last resort -'simple adjustments in lifestyle and behavior can [sometimes] result in an immediate improvement in the condition' (McInnis-Dittrich, 2005, p. 48).

Containment strategies often include some combination of:

i) pads and pants,

ii) assistive technology (e.g. hand-held urinals and special toilet seats), and

iii) catheters (Anders \& Foxley, 2006).

These strategies should follow on, not replace, treatment. '[Containment] methods are associated with a high incidence of urinary tract infection which not only cause physical discomfort but also exacerbate incontinence, and play a large part in increasing mortality' (Wells \& Wells, 1997, p. 330, see also Anders \& Foxley, 2006).

Information can be shared with individuals, families and groups, including other health and social care workers. Getliffe \& Thomas (2007, p. 19) note that the 'lack of education and knowledge relating to continence within the health and social care professions is a limiting factor in service development and delivery.' Fortunately there is now a large amount of high quality information geared to both service providers and service users on the internet (see box below). Self-management (e.g. modifications to clothing and environment to facilitate toileting; toilet 'mapping', toileting regimes) and self-treatment techniques (e.g. bladder floor exercise, weight loss, caffeine and nicotine reduction) (Locher et al, 2002) reflect a self-help approach to bladder health (Asbury \& White, 2001).

\section{Providing emotional support}

Empathic listening and an unconditional positive regard are prerequisite to providing emotional support. Listening is congenial to a biographical or narrative approach to counselling, allowing the social worker to learn about the attitudes, relationships and preferences of the older person (Phillips, Ray \& Marshall, 2006) in his or her own words. It is important to tolerate silence - quickly reassuring an older person may prevent him or her from disclosing further (Gallo-Silver, 2006).

The alert social worker will also be listening for 'enabling stories' where past adversities were successfully negotiated, and reflect these back to the older person (Rolland \& WernerLin, 2006; see also White \& Epston, 1990). In such 'empowering narratives' (White \& Epston, 1990) we locate 'the diction, symbols, metaphors and tools for rebound' (Saleebey, 1996, p. 299). Attitudes and beliefs of the older person and their carers (frequently family members) are important for the social worker to locate and address (Rolland \& Werner-Lin, 2006).

Shifting dependence on others over the life span frequently results in subtle and not so subtle shifts of power (Shield \& Aronson, 2003; Tomita, 2006) which may require sensitive deconstructing by a skilled worker. The caring relationship is temporal and two-way; each 
party to the relationship has something to offer the other over time (Brandon \& Jacks, 1997). Beliefs and perceptions may require reframing where possible 'to create a meaning for the illness situation that preserves [a family's] sense of competency and mastery' (Rolland \& Werner-Lin, 2006, p. 307).

\section{Providing access to resources}

Access to resources may be grounded in a nation's welfare policy as a practical matter, but claims to support are increasingly being advanced on theories of individual and collective human rights, as these have developed over the decades in the United Nations (UN) and other international and national fora (Committee on Economic, Social and Cultural Rights, 2005; Connolly \& Ward, 2008; Humphreys, 2009). As the UN, the International Association of Schools of Social Work and the International Federation of Social Workers have noted (United Nations, 1994), human rights and social justice are the fundamentals of social work practice.

The social worker, now equipped with a biopsychosocial understanding of UI and a map of available continence services in his or her area, advocates with the older person's GP and other health care professionals for an integrated approach to preventative, curative and rehabilitative health care as a matter of right. Consider also supports offered by such NGOs as Alzheimer's New Zealand and the New Zealand Continence Association.

Older persons will sometimes want assistance to meet more generic basic human needs, such as those for ' good housing, adequate income, transport and social networks' (Naughtin \& Schofield, 2009, p. 197). In all of this social workers are careful to work collaboratively with older persons and their whanau and other carers to promote choice in achieving the older person's own goals. 'Practice will be more effective when older people themselves are involved in the process, with outcomes based on their expressed wishes and priorities as far as possible' (Naughtin \& Schofield, 2009, p. 205).

\section{Raising the continence promotion profile with the public and professions}

The International Continence Association has established a Continence Promotion Committee which has done important work in public awareness and professional education (Newman et al, 2002). Public awareness campaigns were instrumental in breaking down the stigma associated with cancer, infertility and mental illness (Fonda \& Newman, 2006). Although the media have been reluctant to showcase continence issues (Fonda \& Newman, 2006; Getliffe \& Thomas, 2007), that is beginning to change. Adopting simple preventative screening for UI in your social work practice, followed by assessment and intervention where indicated, can and will also play a role in educating both older persons and professional colleagues (Newman et al, 2002).

\section{Influencing and improving continence policy}

The older persons' service social worker must work constructively to change local and national health care policies and to bring about the promotion, development, funding and implementing of integrated continence services that deploy evidence-based pathways for treating UI for older persons requesting treatment. In an era of public borrowing, effectively shifting some of the costs of our health care onto our children and their children, proponents of new spending will need to make a compelling business case if they expect planners and funders to take note. 
This involves cost estimates for treating UI, evaluating the economic burden if UI is left untreated, and comparing the costs and benefits of the alternatives (Getliffe \& Thomas, 2007). In the area of UI an ounce of prevention is truly worth a pound of cure. It makes far more sense to resource the specialist physiotherapists and continence nurse specialists at the front end, than the hospitalisation and the medical and social costs that frequently results after a urinary tract infection or a fall.

\section{Conclusion}

As social workers become actively involved in prevention, outcomes for both older persons and the health system will be improved and scarce resources will be conserved (Browne, 2006). In this process, the role of health care social workers in the interdisciplinary team setting will also be enhanced. As one health care social worker has observed, when;

...social workers can show that they reduce medical costs by reducing hospital stays, increasing patient satisfaction and quality of life, and reducing morbidity and mortality, they can maintain their presence in health organisations (Browne, 2006, p. 38).

When an intervention or other set of measures leads to both a better quality of life and a more efficient use of scarce resources, service providers have a moral imperative to act.

\section{Internet resources}

New Zealand Continence Association

Carers NZ

Continence Foundation of Australia

Bladder and Bowel Website (Australian

Department of Health and Ageing)

Canadian Continence Foundation

Hong Kong Continence Society

Indian Continence Foundation

International Continence Association (Professional Association)

Bladder and Bowel Foundation (UK)

National Association for Continence (USA)

Simon Foundation for Continence (USA)

World Federation of Incontinence Patients

(International Service Users)
Http: / / www.continence.org.nz /

Http: / / www.carers.net.nz /

Http: / / continence.org.au

Http: / / www.bladderbowel.gov.au /

Http: / / canadiancontinence.ca

Http: / / www.hkcs.hk

Http:/ / www.indiancontinencefoundation.org

Http: / / www.icsoffice.org

Http:/ / www.bladderandbowelfoundation.org

Http: / / www.nafc.org

Http: / / simonfoundation.org

Http: / / www.wfip.org 


\section{References}

Abrams, P., Cardozo, L., Fall, M., Griffiths, D., Rosier, P., Ulmsten, U., et al. (2003). The standardisation of terminology in lower urinary tract function: Report from the standardisation sub-committee of the International Continence Society. Urology, 61(1), 37-49.

Anders, K., \& Foxley, S. (2006). Catheters; pads and pants; appliances. In L. Cardozo \& D. Staskin (Eds). Textbook of female urology and urogynecology (2nd ed.), pp. 541-561. UK: Informa Healthcare.

Andreae, D. (1996). Systems theory and social work treatment. In F. Turner (Ed.), Social work treatment (4th ed.). New York: The Free Press.

Asbury, N. \& White, H. (2001). Don't make me laugh. How to feel better about living with a weak bladder. North Tyneside: Northumbria Healthcare NHS Foundation Trust.

Avery, K., Donovan, J., Peters, T., Shaw, C., Gotoh, M., \& Abrams, P. (2004). ICIQ: A brief and robust measure for evaluating the symptoms and impact of urinary incontinence. Neurourology and Urodynamics, 23(4), 322-30.

Berkman, B., Chauncey, S., Holmes, W., Daniels, A., Bonander, E., Sampson, S., \& Robinson, M. (1999). Standardized screening of elderly patients' needs for social work assessment in primary care: Use of the SF-36. Health E Social Work, 24(1), 9-16.

Brandon, D., \& Jack, R. (1997). Struggling with services. In J. Norman and S. Redfern (Eds.), Mental health care for elderly people (pp. 247-257). New York: Churchill Livingstone.

Brashler, R. (2006). Social work practice and disability issues. In S. Gehlert and T. Browne (Eds.), Handbook of health social work (pp. 448-470). New Jersey: John Wiley \& Sons.

Browne, T. (2006). Social work roles and health care settings. In S. Gehlert and T. Browne (Eds.), Handbook of health social work (pp. 23-42). New Jersey: John Wiley \& Sons.

Burke, P. \& Parker, J. (2007). Introduction. In P. Burke and J. Parker (Eds.), Social work and disadvantage: Addressing the roots of stigma through association. Philadelphia: Jessica Kingsley Publishers.

Butler, R. (1975). Why survive? Being old in America. New York: Harper and Row.

Carers NZ, (25 February 2009). Carers stressed, and dissatisfied with services. Carer NZ News Media Releases. Retrieved May 5, 2009, from the World Wide Web: http: / / www.carers.net.nz/ modules.php?op=modload\&name=New s\&file $=$ article \&sid $=406 \&$ mode $=$ thread $\&$ catid $=10 \&$ order $=0 \&$ thold $=0$

Committee on Economic, Social and Cultural Rights (2005). General Comment No. 14: The right to the highest attainable standard of health (Article 12 of the International Covenant on Economic, Social and Cultural Rights). In S. Gruskin, M. Grodin, \& G. Annas (Eds.), Perspectives on health and human rights, (pp. 442-462). Abingdon, Great Britain: Routledge.

Compton, B., Gallaway, B., \& Cournoyer, B. (2005). Social work processes (7th ed.). Belmont: Brooks / Cole - Thompson Learning.

Connolly, M., \& Ward, T. (2008). Morals, rights and practice in the human services: Effective and fair decision-making in health, social care and criminal justice. London and Philadelphia: Jessica Kingsley Publishers.

Cooper, J. (1997). Urinary incontinence in the elderly: Pharmacotherapy treatment. Binghamton, New York: The Pharmaceutical Products Press.

Davey, J. (2002). Needs assessment for the over 65s: Overview of literature to inform the guidelines development team. Wellington: New Zealand Institute for Research on Ageing.

Diwan, S., \& Balaswamy, S. (2006). Social work with older adults in health-care settings. In S. Gehlert and T. Browne (Eds.), Handbook of health social work (pp. 305-334). New Jersey: John Wiley \& Sons.

Domenelli, L. (2002). Anti-oppressive social work theory and practice. Hampshire: Palgrave Macmillan.

Fonda D., \& Newman D. (2006). Tackling the stigma of incontinence - promoting continence worldwide. In L. Cardozo \& D. Staskin (Eds). Textbook of female urology and urogynecology (2nd ed.) (pp. 75-80). UK: Informal Healthcare.

Gallo-Silver, L. (2006). Human sexuality and physical intimacy. In S. Gehlert and T. Browne (Eds.). Handbook of health social work (pp. 417-447). New Jersey: John Wiley \& Sons.

Getliffe, K. \& Thomas, S. (2007). Incontinence in perspective. In K. Getliffe \& M. Doman (Eds.), Promoting continence: A clinical and research resource (3rd ed.) (pp. 3-23). Edinburgh: Ballière Tindall.

Greene, R. (1999). The ecological perspective: An eclectic theoretical framework for social work practice. In R. Greene and P. Ephross (Eds.), Human behaviour theory and social work practice (pp. 259-300). Hawthorne (NY): Aldine de Gruyter.

Greene, R. (2000). Social work with the aged and their families. Hawthorne (NY): Aldine de Gruyter.

Hope, C. (2007). Promoting continence positively. Journal of Community Nursing, 21(11), 24-26.

Horrocks, S., Somerset, M., Stoddart, H., \& Peters, T. (2004). What prevents older people from seeking treatment for urinary incontinence? A qualitative exploration of barriers to the use of community continence services. Family Practice 21(6), 689-696.

Hughes, C. (1997). Depression and mania in later life. In J. Norman and S. Redfern (Eds.), Mental health care for elderly people (pp. 141-161). New York: Churchill Livingstone.

Humphries, C. (2009). Foreward. In M. Connolly and L. Harms (Eds.), Social work: Context and practice (pp. iii- ). South Melbourne: Oxford University Press.

Jorgensen, D., Parsons, M. \& Jacobs, S. (2009). The experience of informal caregivers in New Zealand. Auckland: University of Auckland. 
Kairuz, T., Zolezzi, M., \& Fernando, A. (2005). Clinical considerations of antidepressant prescribing for older patients. New Zealand Medical Journal, 118(1222), 1-11.

Kane, R. (2006). Standardised measures commonly used in geriatric assessment. In B. Berkman and S. D' Ambruoso (Eds.). Handbook of Social Work in Health and Aging (pp. 737-748). New York: Oxford University Press.

Landi, F., Cesari, M., Russo, A., Onder, G., Lattanzio, F., \& Bernabei, R. (2003). Potentially reversible risk factors and urinary incontinence in frail older people living in community. Age and Ageing, 32(2), 194-199.

Lara, C., \& Nancy, J. (1994). Ethnic differences between Maori, Pacific Island and European New Zealand women in prevalence and attitudes to urinary incontinence. New Zealand Medical Journal, 107(998 Pt1), 374-76.

Locher, J., Burgio, K., Goode, P., Roth, D., \& Rodriguez, E. (2002). Effects of age and causal attribution to aging on health-related behaviors associated with urinary incontinence in older women. The Gerontologist, 42(4), 515-521.

McInnis-Dittrich, K. (2005). Social work with older adults: A biopsychosocial approach to assessment and intervention (3rd ed.). Boston: Allyn \& Bacon.

Mitteness, L. \& Barker, J. (1995). Stigmatising a 'normal' condition: Urinary incontinence in late life. Medical Anthropological Quarterly, 9(2), 188-210.

Myers, J. \& Schwiebert, V. (1996). Competencies for gerontological counseling. Alexandria (VA): American Counseling Association.

Naughtin, G., \& Schofield, V. (2009). Working with older people. In M. Connolly and L. Harms (Eds.). Social work: Context and practice (pp. 195-208). South Melbourne: Oxford University Press.

Newman, D., Denis, L., Gartley, C., Gruenwald, I., Lim, P., Millard, R., \& Roberts, R., (2002). Promotion, education and organization for continence care. In P. Abrams, L. Cardozo, S. Khoury, \& A. Wein (Eds). Incontinence, Proceedings from the Second International Consultation on Incontinence (pp. 937-964). Plymouth UK: Health Publication.

Perry, S. (2008). Prevalence of urinary incontinence: A review of the literature. In J. Haslam \& J. Laycock (Eds.). Therapeutic management of incontinence and pelvic pain (2nd ed.) (pp 3-6). London: Springer.

Phillips, J., Ray, M., \& Marshall, M. (2006). Social work with older people (4th ed.). Basingstoke: Palgrave.

Rolland, J., \& Werner-Lin, A. (2006). Families, health, and illness. In S. Gehlert and T. Browne (Eds.), Handbook of health social work (305-334). New Jersey: John Wiley \& Sons.

Saleebey, D. (1996). The strengths perspective in social work practice: Extensions and cautions. Social Work, 41, 296-305.

Saleebey, D. (2005). The strengths perspective: Principles and practices. In B Compton, B. Galaway \& B. Cournoyer (Eds.), Social work processes (7th ed.). Belmont: Brooks / Cole - Thompson Learning.

Schultheiss, D., Höfner. K. , Oelke M., Grüewald, V., \& Jonas, U. (2000). Historical aspects of the treatment of urinary incontinence. European Urology, 38(3), 336-43.

Scrutton, S. (1997). Counselling: Maintaining mental health in older age. In J. Norman and S. Redfern, (Eds.), Mental health care for elderly people (pp. 271-286). New York: Churchill Livingstone.

Seymour, W. (1998). Remaking the body: Rehabilitation and change. London: Routledge.

Shield, R., \& Aronson, S. (2003). Aging in today's world: Conversations between an anthropologist and a physician. New York: Berghahn Books.

Stewart, E. (2006). The roles of the continence nurse specialist. In L. Cardozo \& D. Staskin (Eds), Textbook of female urology and urogynecology (2nd ed.) (pp. 81-90). UK: Informal Healthcare.

Taylor, B., \& Donnelly, M. (2006). Professional perspectives on decision making about the long-term care of older people. British Journal of Social Work, 36, 807-826.

Tomita, S. (2006). Mistreated and neglected elders. In B. Berkman and S. D'Ambruoso (Eds.), Handbook of Social Work in Health and Aging, pp. 219-230. New York: Oxford University Press.

United Nations (1994). Human rights and social work: A manual for schools of social work and the social work profession. Geneva: UN Centre for Human Rights.

Wagg, A., Potter J., Peel, P., Irwin, P., Lowe, D., \& Pearson, M. (2008). National audit of continence care for older people: Management of urinary incontinence. Age and Ageing, 37, 39-44.

Weidenbohm, K., Parsons, M., Dixon, R., Keeling, S., Senior H., \& Brandt, T. (n.d.). The interRAI evaluation: The exploration of the interRAI training programme implemented across five District Health Boards in New Zealand. Auckland: University of Auckland.

Wells, C., \& Wells, J. (1997). Reducing challenging behaviour of elderly confused people: A behavioural perspective. In J. Norman and S. Redfern, (Eds.), Mental health care for elderly people (pp. 315-338).

Whitbourne, S. (2005). Adult development and aging: Biopsychosocial perspectives (2nd ed.). New Jersey: John Wiley and Sons.

Wilson, K., Ruch, G., Lymbery, M., \& Cooper, A. (2008). Social work: An introduction to contemporary practice. Harlow: Pearson Education Limited.

White, M., \& Epston, D. (1990). Narrative means to therapeutic ends. New York: Norton. 